\title{
PROBLEMS OF THE LABOR MARKET: A CASE STUDY OF BELGRADE
}

\author{
Ljiljana Živković* ${ }^{* 1}$ \\ "University of Belgrade - Faculty of Geography, Belgrade
}

\begin{abstract}
High unemployment accompanied by a decline in production is one of the major economic and social problems in Serbia. The existing economic problems, which are defined by structural mismatch, non-competitive production and traditional means of production is accompanied by an increase in the problem of poverty, due to the participation of elderly and dependent persons, a decline in the number of employees. Markets are a way to organize economic activity and can only be successful if the activities are organized in a way that enhances the overall economic benefit. If this does not happen, there is a market failure which is the situation in which the market alone fails to achieve full efficiency. Taking into account of territorial disparities in economic potentials of development, the aim of the paper is to point out the problems facing the labor market in Belgrade. The author tried to show the basic characteristics of Belgrade during his work, as well as economic, traffic and market a significant city in Southeastern Europe. The effects, instruments and benefits of market policy and alternatives to overcome existing constraints, opportunities and solutions are presented. Activities to improve the productivity and quality of work must be planned according to the expected changes in the economic structure, according to the greater involvement of Belgrade in the European and regional economic integration, and with optimal use of domestic resources to the comparative advantages of the country.
\end{abstract}

Key words: Labor market, Belgrade, unemployment, economic policy, economic problems.

${ }^{1}$ Corresponding author: Lj. Živković, University of Belgrade - Faculty of Geography, Studentski trg 3/III, 11,000 Belgrade, Serbia; e-mail: ljzivkovic@gef.bg.ac.rs 


\section{Introduction}

The basic components of the labor market as the demand for labor and the supply of labor with the appearance of specific factors. The labor market is part of the economy consisting of unequal skilled workers to heterogeneous jobs in various economic activities. In the case of such heterogeneity that come with the supply side and the demand side, it is difficult to expect the achievement of optimum market (Aleksić, Vuksanović, 2017). With regard to the specific features and characteristics arising from the labor market compared to the traditional market of products that can be competitive or non-competitive. Labor market governed by the forces of supply and demand, and workers find employment through the labor market. This market includes the preparation of the workers, their recruitment, promotion, dismissals, waiting for employment, competition, job search and on the job. Basic specific labor market stems from the characteristics of the goods and services at one side and work as a human activity, on the other side. On the specifics of the labor market is influenced by numerous factors such as the inferior bargaining position of workers arising from the fact that the market is almost always there is excess supply. This situation automatically puts employers in a more favorable position. While a worker is in a situation of lack of jobs and the need for employment, employers are in a position to choose between the number of unemployed.

Serbia is the problem of high unemployment facing for many years. In the first decade of the $21^{\text {st }}$ century, Serbia is characterized by the presence of certain restrictions, which are the result not only of transition effects, but many unfavorable tendencies inherited from the previous period. One of the limitations are structural mismatches on both the supply and the demand side of the labor market in Serbia, which have a long-term character (Leković, Marjanović, 2011). A serious problem is the emigration of highly educated young people abroad, which is a great loss for the country. The most vulnerable groups of the unemployed, they are young people, unskilled workers, groups of unemployed that long job search for many reasons, as well as migrant-settlers (Radovanović, Maksimović, 2010). Given that employers other than educational attainment, employment, often take into account the additional forms of professional development, language skills, ability to work in a team, responsible attitude towards the environment, it is essential that young people through various courses acquire additional competencies (Jovanović at al., 2011).

The labor market in recent years, marked changes that have occurred as a result of rapid technological development of modern society. It is necessary 
to consider changes in the labor market, but also point to the still present regional disparities. The aim of the paper is to point out the movement of supply and demand of jobs and labor, their tendencies, regularity and legality. Bearing in mind the theoretical methodological concept, as well as the research to date have been set initial hypotheses. These indicate that the labor market trends defined by certain rules and trends over a longer period of time. One of the trends related to the existence of non-compliance in Serbia between the needs of the labor market and the education system. Another tendency includes informal employment, which significantly participate in total employment in Serbia. The structure of the paper consists of an introductory part stating the importance and actuality of the topic, and then defines the objectives and hypotheses. Through previous research provides an overview of the labor market in the Member States of the European Union and countries in the region. Methodology of research shows that institutions have data on the labor market in the territory of Belgrade and the entire Serbia. Analyzing the data, the author points to the long-term unemployment, informal employment and the lack of education and the labor market. In conclusion formulated proposals to improve the situation on the labor market of the City of Belgrade.

\section{Previous research}

The European Union has for many years an active policy in the field of labor market. One of the priorities of the Union as a whole and each of its individual Member States is a decrease in the unemployment rate. The average employment rate in the EU 27, measured in relation to the population aged $15-64$ in 2009 was $64.6 \%$. The employment rate is continuing to grow in the period 2000-2008. However, the global economic crisis that affected the decline in overall economic activity of the EU Member States in 2009 has led to a decline in employment of $1.3 \%$ compared to 2008 (ec.europa.eu/eurostat).

The highest employment rate in the European Union have the Netherlands $(77.0 \%)$ and Denmark $(75.7 \%)$. In contrast, the lowest rate was observed at Malta (54.9\%) and Hungary (55.4\%). Observed by the Member States, the highest unemployment rate in the period 2000 to 2008, there were Spain, Slovakia, Hungary and Greece. In the early period of this group belonged to Bulgaria, however dynamic growth in employment this country in 2008 managed to reduce unemployment to 5.6\% (ec.europa.eu/eurostat).

The economic crisis that occurred in mid-2008 variously have affected some 27 EU Member States, so that there is a further difference in 
their unemployment rates. According to Eurostat data, the most affected is Spain, which in 2009 reached an unemployment rate of $18 \%$, followed by Latvia (17.1\%), Lithuania (13.7), Slovakia (12.0\%), Ireland (11.9\%), Hungary $(10.0 \%)$ and Greece $(9.5 \%)$.

Common measures of EU regional policy helps the education and training of workers in order to efficiently find a job. Training work potential creates greater opportunities for people to find jobs in the labor market, and companies will have the opportunity to achieve greater competitiveness and growth, particularly in new sectors. Also assists young people and those who have been unemployed and with lower qualifications. Support also consists in equalizing opportunities for women and men to get a job in the labor market (Union Europeenne, Politique regionale 2007).

Although the situation on the labor market is still problematic, growth in the region brought new jobs. Employment growth accelerated in many countries, which has increased the employment rate to 2\% in June 2015 to $4.5 \%$ in June 2016 (P3C, 2016). By September 2016, Albania recorded the highest employment growth of $8.5 \%$, not far behind is not Serbia with $7.2 \%$, which amounts to an average of almost $6 \%$ of the average employment growth in the region throughout 2016. Employment growth has been achieved because Albania reduce the non-formal sector in Serbia has been a recovery of production and good agricultural season, which generated an expansion of non-formal employment. To a lesser extent, growth was recorded and the FYR Macedonia and Montenegro. In Bosnia and Herzegovina, recent reforms of the labor market has yet to make a significant impact on increased employment, which decreased by 2.6\% compared to June 2016 (www.worldbank.org).

Reducing unemployment depends on active labor market policies. Unemployment decreased in almost all countries in the region. This was achieved despite the increased participation of the labor force in Serbia and Albania. In FYR Macedonia, lower unemployment was recorded fiscally supported active labor market policies and the extent of private sector employment, particularly in construction. Montenegro is the only country where the unemployment rate has increased because of the life-long benefits to mothers with three or more children and to encourage them to stop working (www.worldbank.org).

Despite recent positive developments in the region, unemployment remains high. Unemployment has averaged 20\% in 2016. More than $70 \%$ of the population are long-term unemployed (P3C, 2016). The youth unemployment rate is double as high that of the working age population. 


\section{Methodological approach}

Evidence in the field of labor, employment, unemployment and education deals with several institutions in Serbia. Data on businesses, employment and education can be obtained from the Agency for Business Registers, the Republic Institute for Statistics and the City Institute for Informatics and Statistics. The National Employment Service is responsible for recording data on employment and unemployment. Ministry of Education, Science and Technological Development, the Institute for Improvement of Education, Republic Agency for Development of Small and Medium Enterprises and the Institute for Pension and Disability Insurance also evidence the above mentioned information. However, it should be noted that the comparison and analysis of data is difficult because there is no methodological harmonization between the evidence dealt with by the relevant institutions (Dimov, 2007).

Data on employment who are registered with the National Employment Service (NSZ) include two categories: total employment and the employment of persons registered as unemployed. In both cases, statistics are evidence according to the activity and level of education, but not professions. Classification of Activities (Law on classification of activities and register of classification units, passed in 1996, with the application of 01.01.1998) according to which the recorded statistics of employment in the National Employment Service has 17 work field, 24 areas of work and 364 interior, specific areas of activity. In comparison, the NSZ by model classification JNZ - 19 work field and 75 professions groups recorded statistics demand for professions and fill out jobs, through which can be monitored demand for certain professions. Classification of work field by sorting educational profile benefit the Republic Institute for the Advancement of Education (RZUOV) has 15 field of work.

Analyzing data on employment has resulted in a huge mismatch in the classification system used by the NSZ and RZUOV. It is possible to communicate the following data: status as unemployed evidence to the classification of professions JNZ, demand and fill out (employment) jobs by professions, also according to the classification of activities in the JNZ, as well as employment by level of degree of vocational education (no professions) according to the Classification of activities and register classification units. The Ministry of Labor, Employment Veteran and Social Affairs, the Law on Evidence was adopted, who coordinates the evidentiary basis for the statistics department of the ministry with European standards. The National Employment Service is consistent unified information system containing all the evidence that this service represented. Were unified conceptual and methodological approach- 
es in recording evidence through direct comparison with the situation in the labor markets in the European Union.

\section{Results and discussion}

The main characteristic of the state of Serbian economy in recent decades has low employment and high unemployment, which is one of the major economic and social problems of the country. The employment rate lags far behind the Lisbon target (70\% of employment), and the unemployment rate, according to official data shows that every fifth resident of the able-bodied unemployed (P3C, 2010). The reasons for these adverse trends in employment are, for the most part, the consequences of the transition process. Restructuring and privatization have resulted in the closure of a large number of jobs, privatized enterprises, new jobs are opened very slowly and not enough to be able to absorb all of the requirements expressed by the labor market.

According to data in 2015, the number of active persons in Serbia amounted to 3126100 persons (decreased by 1.3\% compared to the 2014 year). The largest reduction in the contingent active persons in the region of Vojvodina (3.4\%). Compared to 2014, the number of active women decreased by $1.4 \%$, while the number of active men by $1.2 \%$. Data for active persons shows that the Republic of Serbia in 2015 was 2,574,200 persons employed (employment rate increased by $0.6 \%$ compared to 2014). The employment rate for men it was $50.2 \%$ and $35.3 \%$ for women. During the same period, the number of unemployed amounted to 551.900 (the unemployment rate decreased by $1.5 \%$ compared to 2014). The unemployment rate for men was $16.8 \%$ and for women $18.8 \%$. Number of inactive persons in 2015 amounted to $2,933,900$ persons (increased by $0.1 \%$ compared to 2014 ). The inactivity rate for women was significantly higher (56.5\%) compared to the inactivity rate for men (39.7\%) (P3C, 2016). According to the National Employment Service required qualifications in the Republic of Serbia in 2015 amounted to $0.46 \%$ for primary school, $52.52 \%$ for secondary school, high school $35.79 \%$, master $11.18 \%$, master's degree $0.02 \%$ and doctorate $0.03 \%$ (Figure 1 ).

Unemployment is a complex problem for which the individual may have a direct permanent consequences manifested in falling living standards and social vulnerability. In addition, Serbia faces significant demographic and social problems such as high participation of the elderly persons (over 65 years) and the emigration of young people (Vujadinović et al., 2013). Because of its complexity, solving these problems involves a comprehensive and multi- 
disciplinary approach. It is necessary to consider all the restrictions and apply the most effective means available to the labor market, as well as adequate instruments of economic policy and system. In addition to measures of active policy measures and implementation of complex programs of economic and regulatory reform as a way to improve economic conditions, which will achieve a better labor market outcomes (Leković, Marjanović, 2011).

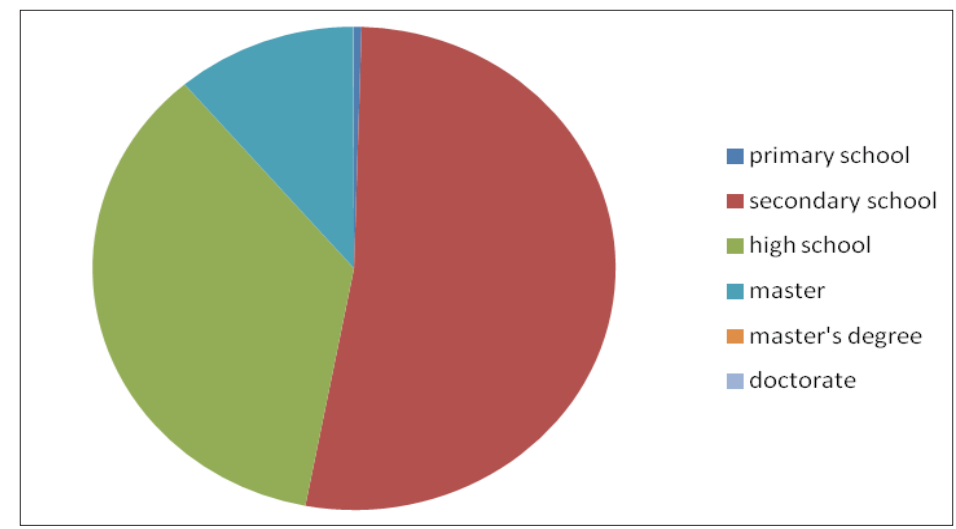

Figure 1 - Required qualifications in the Republic of Serbia in 2015 Source: Национална служба за запошљавање, 2016

Increased employment is achieved by a combination of economic and social policies. To get unemployment down to a lower level, the necessary reforms are:

- the demand for jobs by creating a business environment that is conducive to investment and growth in economic activity;

- offer jobs through the reform of the education system;

- labor market more flexible by removing the deficiency of labor legislation and the expansion of communication between the employes and the employer (Mijatović, 2012).

Experiences of developed market economies, especially those with a social-market orientation, based on the principles of competition and include a unique set of constituent and editorial principles, as the basis for the regulation of the labor market. In this way, the appropriate regulation of the labor 
market, long-term will be a function of the realization of economic interests expressed in the sustainability of the growth and development of economy and society, and at the same time will represent a stable instrument to improve living standards (Leković, Marjanović, 2011). In order to create conditions for the functioning of the labor market, it is necessary to improve its transparency, as well as to facilitate the mobility of economic operators and flexibility benefits. This includes establishing a complex institutional regulation of the labor market, within which moving workers and employers when making decisions. Institutional regulation of the labor market make the laws, procedures and functioning institutions. Editing to these areas is provided greater mobilization potential of the labor market to reduce unemployment and a expansion range of employment (Leković, Marjanović, 2011).

Successful development of the City of Belgrade, depends largely on economic competitiveness and accessibility. Belgrade's competitiveness in the global economy is a certain degree of sustainable utilization of territorial capital and potential of the city. The principle of accessibility is conditioned sustainable development, reconstruction and modernization of the network infrastructure, especially the regulation of traffic. Rational use of the geographical position of the City of Belgrade, as well as possibilities to adapt its economic structure of modern development processes (globalization, technological revolution, competition in the global and integrated markets) and increasing competitive advantage in regional integration movements, the City of Belgrade will get a significant place and role in the international division work. The transition in Serbia is facing regional and local economy with increasing challenges. The process of globalization affects the economy of the city and brings new opportunities and increased restrictions.

Analysis of the data relating to the economically active population City of Belgrade (44\%), there are significant differences, which are reflected in the percentage of persons perform professions (36\%) compared to the unemployed (8\%). Economically non-active population in Belgrade city belongs to $56 \%$. Of that number, children under 15 years of age account for $14 \%$, pensioners $24 \%$, pupils/students who are 15 years and over $8 \%$ of persons who perform only household chores in their household and other persons 10\% (Figure 2). Taking into account the total population of the City of Belgrade, the largest percentage of those who perform professions, followed by pensioners and children under 15 years old. The reasons why the unemployed await a new job for a long time are numerous. The most common reason is lack of vacancies. Also, one of the reasons is that the workers who are long-term unemployed lost their jobs due to restructuring. Jobs require a certain level of education and skills. Therefore, 
it is particularly important to focus attention on the quality and type of program, competence of trainers, development of skills of workers through education and their role in meeting the needs of the labor market.

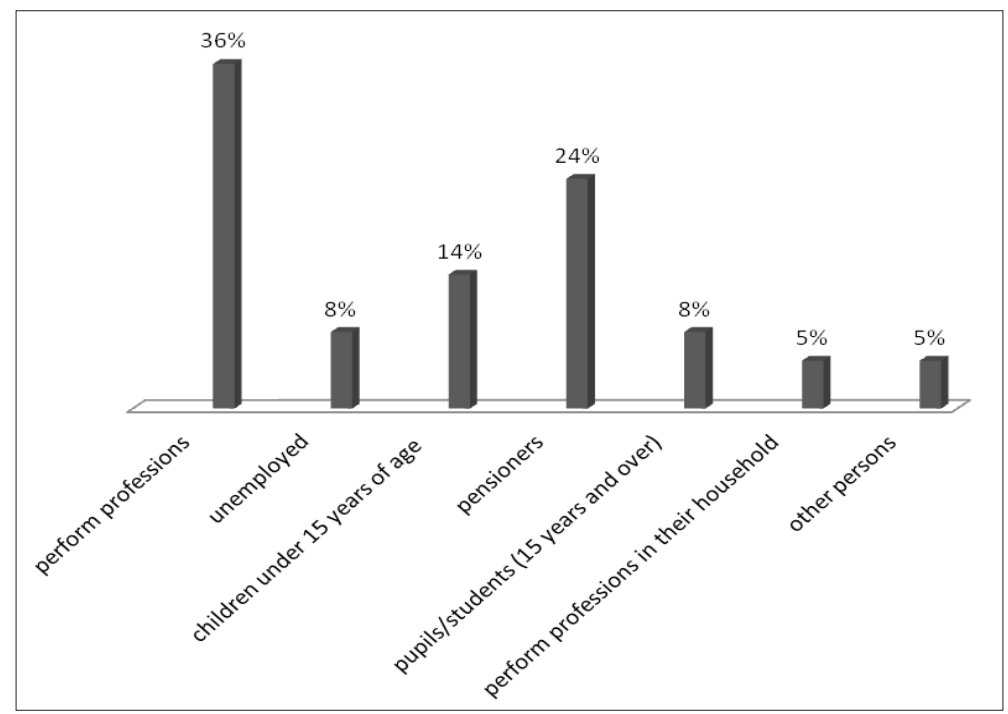

Figure 2 - Economic activity in the City of Belgrade Source: P3C, 2011

Recovery of the city's economy has been present since 2000 through a five-year dynamic and steady constant growth of the social product, at an average annual rate of 5.6\% (2001-2005), which allowed multiple growth of the social product per capita (Градски завод за информатику и статистику, 2007). Gradually changing economic structure $(60 \%$ of the social product is created in the tertiary sector, and trade and other activities generate $1 / 3$ of the social product), taking primacy over the industry. The economic structure of Belgrade dominated industry tertiary-quaternary sector defines its role as the organizational, administrative, service, educational, scientific research and cultural center. At the same time modernize the industry, defining Belgrade as the industrial center of an important place in the wider regional context. Employment increased from 430,000 in 2000 to 630,000 in 2008. During 2011, 67\% were employed in the service sector. In particular, the observed increase in employees in independent activities. In Belgrade work for 40.2\% of all employees in Serbia (P3C, 2011). 
Analysis of the data relating to the economically active population Belgrade City by gender can be seen that a higher percentage of males $(23.8 \%)$, while uniform in those who perform a profession $(18.7 \%$ males and $18.1 \%$ females). When it comes to unemployment, also are not big differences in the percentages relating by gender the population. Those who worked sometimes make up $6.1 \%$, and the percentage of first-time job seekers was $3.1 \%$. Of the total population is from $9.2 \%$ unemployed (Table 1).

Table 1 - Economic activity in the City of Belgrade by gender

\begin{tabular}{|c|c|c|c|c|c|c|c|}
\hline \multirow{3}{*}{ City } & \multirow{3}{*}{ Gender } & \multirow{3}{*}{$\begin{array}{c}\text { Total } \\
(\%)\end{array}$} & \multicolumn{5}{|c|}{ Economically active } \\
\hline & & & \multirow[b]{2}{*}{ All } & \multirow{2}{*}{$\begin{array}{c}\text { Perform } \\
\text { professions }\end{array}$} & \multicolumn{3}{|c|}{ Unemployed } \\
\hline & & & & & All & $\begin{array}{c}\text { Worked } \\
\text { sometimes }\end{array}$ & $\begin{array}{l}\text { Fiirst-time } \\
\text { job seekers }\end{array}$ \\
\hline \multirow{3}{*}{ Belgrade } & $\mathrm{s}$ & 100 & 44.7 & 36.8 & 9.2 & 6.1 & 3.1 \\
\hline & $\mathrm{m}$ & 47.3 & 23.8 & 18.7 & 5.1 & 3.1 & 2.0 \\
\hline & $\mathrm{f}$ & 52.7 & 20.9 & 18.1 & 4.1 & 3.0 & 1.1 \\
\hline
\end{tabular}

Source: P3C, 2011

The development of commercial activities in Belgrade is characterized by expressed polycentricity and decentralization of office space in the City which is the basic development orientation. The main aim of the city's economy is dynamic, coherent and competitive development in conformity with the development trends of Europe and the world. Transregional integration activity and the international division of labor based on the principles of sustainability and profitability, knowledge, market confirmed the quality of goods and services. Development of infrastructure, investment in knowledge, encouraging the development of small and medium enterprises, as well as improving the system of public financing can affect change in the existing economic structure of the city.

The concentration of production activities in periurban areas increases along with the basic traffic corridors, as well as in the neighboring municipalities in the contact zone, and the narrower area of the City is uninstalled. The long term aim of agricultural development is the establishment of a competitive and market-oriented sector based on intensive production and high environmental standards. New technologies contribute to the conservation of natural resources and achieving compliance with the growing demand of the Belgrade market. They promote peri-urban parts of the city through 
the gradual improvement of living standards, which should support appropriate agricultural policy, financial and legal framework. This includes increasing productivity and competitiveness, improving techniques, technology and quality of agricultural production. The modernization of the food industry through the introduction of new technologies and standards, better connectivity with primary agricultural production and the development of new processing capacity based on available raw materials will significantly increase production and improve its structure.

The concept of economic development based on the development of the functions of Belgrade as a center of tertiary services: trade, transportation, financial, tourism and construction. The most important territorial capital for the development of a modern, profitable and competitive economy of the city consists of geographical location, land, water and energy potential and human resources. To create an attractive business environment attractive for investment, the City strives to provide adequate institutional, organizational, technical and financial conditions.

\section{Conclusion}

Belgrade, as a regional center, should make use of its resources in order to create a competitive economy, economic activity in line with its potential, to respect and promote specificities, supporting the development of small urban centers and provide greater employment as one of the most important indicators of economic and social development. It is necessary to improve the production characteristics of the formation of market-profiled, modern production structure, with intensive development of small and medium-sized enterprises and with the implementation of the measures and instruments to attract competitive and profitable industrial activity. To be listed, as well as numerous other restrictions that characterize the labor market in Serbia overcome, we need a comprehensive economic policy measures, but also active labor market policies.

The main aim of the new employment policy implies the establishment of an efficient, stable and sustainable employment growth trend until 2020. According to the process joining, employment policy, as well as the activities of the institutions, labor market must completely harmonize with the EU while reducing the differences in labor market indicators.

The adoption and application of technical and technological achievements is necessary given that the global markets are becoming increasingly 
demanding. Employers require adequately trained workers with specific skills and work organization. It follows that flexible labor markets tend to greater economic growth, partly because companies become more competitive and profitable, and in economies in transition to increase competitiveness and long-term economic growth leads to higher employment.

\section{Acknowledgements}

The paper is the result of the research within the project no. 176008 funded by the Ministry of Education and Science of the Republic of Serbia.

\section{References}

Aleksić, D., Vuksanović, N. (2017). Ima li diskriminacije na tržištu rada? Slučaj Srbije u jeku ekonomske krize. Ekonomske ideje i praksa, 24, 67-86.

Dimov, J. (2007). Srednje stručno obrazovanje i potrebe tržišta rada u Beogradu. Beograd: Centar za obrazovne politike i Alternativna akademska obrazovna mreža.

Eurostat (2010). Europe in Figures - Eurostat Yearbook 2010. Brusseles: Eurostat.

Jovanović, S., Živković, Lj., Miljković, O., Anđelković, S., Živković, N. (2011). Interdependance of the predictors of environmentally responsible behaviour. Journal of Environmental Protection and Ecology. vol. 12, 4A, 2335-2340.

Leković, V., Marjanović, G. (2011). Regulatorni aspekti i reforme na tržištu rada. U: Zubović, J. (2011). Aktione mere na tržištu rada i pitanja zaposlenosti. Beograd: Institut ekonomskih nauka, 387-410.

Mijatović, B. (2012). Politike za povećanje zaposlenosti i konkurentnosti radne snage. Srbija.

Radovanović, V., Maksimović, M. (2010). Tržišta rada i (ne)zaposlenost u Evropskoj uniji i Srbiji - regionalni aspekt. Zbornik radova Geografskog instituta "Jovan Cvijic“" SANU, 60(2), 59-74.

Union Europeanne. Politique regionale. (2007). La politique de cohésion 20072013. Commentaires et textes oficiels. Brusseles: Commission européenne.

Vujadinović, S., Šabić, D., Joksimović, M., Golić, R., Živković, Lj., Gatarić, D. (2013). Asylum seekers from Serbia and problems of returnees: Why Ser- 
bia is among the worlds leading countries in number of asylum seekers. Dve domovini, razprave o izseljenstvu. Inštitut za slovensko izseljenstvo in migracije ZRC SAZU, Ljubljana 2013. br. 37, str. 53-68.

World Bank Group (2017). Zapadni Balkan: redovni ekonomski izveštaj. br. 11. Macroeconomics \& Fiscal Management.

Available at: www.worldbank.org/eca/seerer/

Градски завод за информатику и статистику (2007). Београд.

Национална служба за запошљавање (2016). Београд.

Републички завод за статистику Републике Србије (2010). Општине у Републици Србији за 2009. годину. Београд: Републички завод за статистику Републике Србије.

Републички завод за статистику Републике Србије (2011). Општине у Републици Србији за 2010. годину. Београд: Републички завод за статистику Републике Србије.

Републички завод за статистику Републике Србије (2016). Статистички годишњак Републике Србије. Београд: Републички завод за статистику Републике Србије. 